\title{
Prevalence of arthritis among a sample of medical students at Faculty of Medicine, Ain Shams University, Egypt; A Cross-Sectional study.
}

\author{
Yousef M H', Samy H', Gharib M', Amany Mokhtar Abdelhafez ${ }^{2}$. \\ ${ }^{1}$ Medical student, Ain Shams University \\ ${ }^{2}$ Department of Community, Environmental and Occupational Medicine, Faculty of Medicine, Ain Shams \\ University
}

Received: November 2019 Accepted: December 2019

\begin{abstract}
Background: Osteoarthritis is highly endemic disease in Egypt. In high income countries higher arthritis prevalence is associated with low social class, however in low to middle income countries less is known about arthritis prevalence or its predisposing factors. Objective: To measure the prevalence of arthritis among a sample of medical students at Ain Shams University and to identify its probable associated risk factors. Methods: A cross sectional study was carried out at Faculty of Medicine, Ain Shams University. A convenience sample of 340 students was selected. Data were collected using a self-administered questionnaire. Arthritis was assessed using 2 diagnostic methods: 1) doctor-/health care provider-diagnosed arthritis. 2) Four arthritis definitions based on the International Classification of Diseases, Tenth Revision and WHO. Collected data were revised, coded, entered to a personal computer and analyzed using SPSS version 16. Results: The total prevalence of arthritis among the studied students was $8.9 \%$ based on both doctor diagnosis and WHO algorithm $(7.1 \%$ based on doctor diagnosis and $2.1 \%$ based on WHO algorithm). Logistic regression analysis revealed that, residence in urban areas and female gender were the two independent risk factors associated with arthritis $(\mathrm{p}<0.05)$.

Conclusion Findings suggest that further studied are needed across this age group, and proper interventions are needed to overcome the consequences of arthritis later in life.
\end{abstract}

Keywords: Arthritis, Prevalence, medical students, Egypt. WHO algorism, diagnosis

Corresponding author: Hadeer Mohamed Yousef

E-mail: hadeermohamed250@gmail.com

\section{Introduction}

Musculoskeletal disorders have become a serious issue that endangers our healthy aging globally, because these disorders are classified as the second most common cause of disability, measured by years lived with disability (YLDs) (1). According to the WHO the YLDs attributable to osteoarthritis have increased by $75 \%$ from 1990 to 2013, it represents $21 \cdot 3 \%$ of all YLDs $(1,2)$.

Arthritis is the most concerning type of the musculoskeletal disorders (3). According to the Center of disease control and prevention

(CDC), Arthritis means inflammation and/or swelling of one or more joints. It describes more than 100 conditions that affect the joints, tissues around the joint, and other connective tissues. Specific symptoms vary depending on the type of arthritis, but usually include joint pain and stiffness (4). Arthritis is classified into many different types but the most common one is osteoarthritis (5). Arthritis or osteoarthritis became a public health problem that rising up every day, according to a study that was 
held in America, 52.5 million adults in 2010 to 2012 compared to 67 million (25\% of the projected total adult population) adults aged $\geq 18$ years will have doctor-diagnosed arthritis by the year 2030 (6).

Osteoarthritis affects the quality of life, even it makes climbing stairs and walking difficult than any other disease (5). This deterioration of musculoskeletal function affects the ability of working and social activities, in addition, it can be fatal as it may lead to osteoporotic fracture and higher mortality rates than other people in the same age or gender. Moreover, it is the most common reason for total hip and total knee replacement $(5,7)$.

There is a consensus in literature about the risk factors affecting the prevalence of arthritis as gender, joint trauma, exercising sports, genetics and obesity (4-6).

Unfortunately, there is scanty epidemiologic studies which measure the prevalence of arthritis among the youth specifically in Egypt, so the current study was conducted to measure the prevalence of arthritis in a group of medical students at Ain Shams University and to find out the probable risk factors associated with it. This will help the health care organizations in Egypt to take the arthritis among youth as a real threat for their quality of life and to put suitable intervention for them.

\section{Material and Methods}

\section{Study population and design}

A cross-sectional study was carried out at Faculty of Medicine, Ain Shams University. A convenience sample of 340 students was selected from grade one to six from both sexes.

\section{Sample size}

Sample size was calculated based on the following assumptions:
Prevalence of the arthritis $=30 \%(\mathrm{R})$, alpha error $=5 \%$, power $=80 \%$ and degree of precision $=5 \%$. the least required sample size was equal to 323 . Adding 5\% more for possibility of incomplete or unreliable questionnaires, the total sample size $=337$.

\section{Study tools}

Data were collected during July 2018 to January 2019 using the following tools:

\section{Self-administered questionnaire,} consisted of three sections;

Section one for participants' sociodemographic characteristics (age, sex, study grade, residency, father and mother educational levels, smoking status, etc.).

Section two asking for some health related items, self-rated health, ability to do some daily activities, sports and history of chronic diseases.). Self-rated health standard questionnaire of the National Health and Nutrition Examination Survey (NHANES) and National Health Interview Survey(NHIS) was used to assess the students' general health (8).

Section three was used for assessing the presence of arthritis. Arthritis was assessed using 2 diagnostic methods: 1) doctor/health care provider-diagnosed arthritis, self-reported diagnosis of arthritis was based on participant responses to the question; "Have you ever been diagnosed with/told by a health care professional you have arthritis (a disease of the joints; or by other names rheumatism or osteoarthritis)?" (1). 2) Four arthritis definitions based on International Classification of Diseases, Tenth Revision (ICD 10) and WHO (9). As a secondary endpoint, each participant was asked by applying an algorithm developed by the WHO SAGE Wave 1 study team (10); each participant was then classified as having arthritis or not. The questions and the 
algorithm are presented in (Table1). If the student gave history of doctor diagnosed arthritis, he/she was asked about the affected joint and history of irritating symptoms (heaviness numbness hotness) and antiarthritis medications.

\section{Anthropometric assessment}

weight and height measurements were taken using standard techniques. For students more than 20 years old BMI $(\mathrm{Kg} / \mathrm{m} 2)$ was calculated and categorized according to WHO classification (11). For ages less than 20, BMI-for-age was calculated with WHO AnthroPlus v1.0.4 and expressed in Zscores. The students were classified into the following categories wasting" (BMI-for-age $<-2$ Z-scores), "overweight" (BMI-for-age Z-score $>+1$ and $\leq+2$ ), "obese" (BMI-forage Z-score $>+2)$, and "normal weight" (BMI-for-age Z-score -2 to +1 ) $(12,13)$.

\section{Statistical analysis}

Collected data were revised, coded, entered to a personal computer and analyzed using SPSS version 16. All the needed statistical tests for measuring association between presence of arthritis and the different probable risk factors were done and the level of significance used as $\mathrm{p}$ value less than 0.05 .

We found that, $97 \%$ of participants did not answer the question about their smoking status, so this variable was excluded from the analysis. Also, only one gave history of a chronic disease, so this question was also excluded from analysis. Among the studied sample only $9(2.6 \%)$ of all students were underweight (BMI less 18.5), so this category was grouped with the normal body weight category.

\section{Ethical considerations}

The required administrative and ethical committee board approvals were obtained to carry out the study at faculty of medicine, Ain Shams university, in addition verbal consent was obtained from all participants.

\section{Results}

The study comprised a total of 340 students (112 males , 228 females) from first to sixth grades $\left(1^{\text {st }} \quad n=15,2^{\text {nd }} \quad n=45,3^{\text {rd }} \quad n=48,4^{\text {th }} \quad n=77,5^{\text {th }}\right.$ $\mathrm{n}=144,6^{\text {th }} \quad \mathrm{n}=11$ ) enrolled in Faculty of Medicine, Ain Shams University, living in both urban $\operatorname{areas}(n=279)$ and rural areas $(n=61)$, their age ranged from 18 up to 26 years old divided into 3 categories the first one from 18 to 20 years old $(n=104)$, the second one from 21 to 23 years old $(n=221)$ and the third one from 24 to 26 years old $(\mathrm{n}=15)$, all participants were single( Table 2).

Responses to the four questions included in the algorithm for symptom-based arthritis showed that, for all joints, the percentage of participants who had stiffness last more than 30 minutes was $6.2 \% \quad(n=6)$ and the percentage of these participants that their stiffness didn't go away after movement was $7.6 \%(n=7)$ (Table 3$)$.

The total prevalence of arthritis among the studied students was $8.9 \%(\mathrm{n}=30)$ based on both doctor diagnosed and WHO algorithm; [(7.1\%; 3 males,21 females) based on doctor diagnosed and $2.1 \%$ (7 females) based on WHO algorithm] with one case diagnosed by both methods (figure $1)$.

Results revealed that among the students diagnosed with arthritis; prevalence was higher among students resided in urban areas than rural areas $(62.5 \%(n=15)$ based on doctor diagnosed, versus $71.4 \%(n=5)$ based on WHO algorithm). Moreover, the highest prevalence was found in the age group $(21-23)(66.7 \%(n=16)$ based on doctor diagnosed, and $100 \%(n=7)$ based on WHO algorithm). Regarding gender, the highest prevalence was found among females $(87.5 \%$ $(n=21)$ based on doctor diagnosed, and $100 \%$ $(n=7)$ based on WHO algorithm). Moreover, the highest prevalence was found among underweight to normal weight participants (the arthritis prevalence in 
these participants based on doctor diagnosed was $58.3 \%$ and based on WHO algorithm was $57.1 \%)$. Regarding students' grade the highest prevalence was in the fifth grade participants (the total prevalence in this grade based on doctor diagnosed was $45.8 \%$, and based on WHO algorithm was $57.1 \%$ ), Moreover, the highest prevalence was found in participants with faculty graduated fathers and mothers (the total prevalence in these participants is $80 \%$ $(n=24) \quad$ and $\quad 73.3 \% \quad(n=22)$ respectively).Regarding self-rated health, the participants who thought they had fair to poor health represented $26.7 \%$ of diagnosed students versus $4.6 \%$ of non-diagnosed students $(\mathrm{p}<0.05)$, ( Table 4).

We also asked the participants if they had felt any heaviness, numbness or hotness in their joints; students who had been diagnosed by arthritis or had filled the criteria of WHO algorithm had significantly the higher percent of feeling with heaviness, numbness or hotness, $(36.7 \%, 30.0 \%, 20.0 \%$ respectively ) versus ( $11.0 \%, 7.4 \%, 4.2 \%$ respectively ) among the non-diagnosed students $(\mathrm{p}<0.001)$ ( data not shown)

Moreover, students experienced difficulty walking up 10 steps without resting represented $36.7 \%$ among diagnosed students versus $14.7 \%$ of non-diagnosed $(\mathrm{p}<0.05)$, on the other hand difficulty stooping, crouching, kneeling was reported by $43.3 \%$ of diagnosed versus $9.4 \%$ of non-diagnosed students $(p<0.05)$, however no association was found between physical inactivity and occurrence of arthritis ( $p>0.05)$ (Table 5)

Based on doctor diagnosed method, osteoarthritis was the most prevalent type among the different types of arthritis represented $37.5 \%$ followed by rheumatoid arthritis and gout (16.7\% for each), and the most affected joint was the knee $70.8 \% \quad(n=17)$ (figures $2 \& 3$ respectively). Moreover, based on WHO algorithm, the most affected joint was also the knee joint $85.7 \%$ (n=6) (figure 4)

In addition, based on doctor diagnosed method, $70.8 \%(n=17)$ of the diagnosed students were diagnosed at age of 18 years old or more. Participants diagnosed by physical examination represented $70.8 \%(n=17)$ among doctor diagnosed participants. In addition, $54.2 \%(n=13)$ of them had affected joints on both sides. Students who reported taking any medication for arthritis represented $41.7 \%$ $(n=10)$, the medications were prescribed by physician in 9 participants $(90.0 \%)$ and selfprescribed by only one student $(10 \%)$. (data not shown).

Logistic regression analysis revealed that, residence in urban areas (odds ratio $=2.822 \&$ 95\% CI $=1.226-6.497$ ) and female gender (odds ratio $=4.623 \& 95 \% \mathrm{CI}=1.352-15.809$ ) were the two independent risk factors associated with arthritis $(\mathrm{p}<0.05)$ (Table 6).

\section{Discussion}

Arthritis is an increasing problem in the whole world. According to the CDC, by the year 2040 an estimated 78.4 million $(25.9 \%$ of the projected total adult population ) will have doctor-diagnosed arthritis (14). However, till now there is no definite prevalence of arthritis in Egypt specially among the youth. So this study was conducted to measure the prevalence of arthritis among the youth across age, gender, residence, and other variables in a sample consisting of 340 students aged 18 up to 26 years old enrolled in the Faculty of MedicineAin Shams University.

According to our findings, the total prevalence of arthritis among the studied students was $8.9 \%$. The total prevalence of arthritis was significantly higher among female students $(90 \%)$ than males $(10 \%)$, and higher in students who lived in urban areas $(63.3 \%)$ than those who live in rural areas $(36.7 \%)$, and they were the two independent risk factors of arthritis among the studied sample. This is in line with the results reported by CDC where arthritis was more common among American women than men, from 2013 to 2015 , since $26 \%$ of women versus $19.1 \%$ of men had ever reported doctordiagnosed arthritis (15). 
If we have a look on BMI, we can find that the diagnosed students were mostly non obese, this result may be because most students in our sample were non-obese or may be due to the advice carried out by the physicians.

According to our findings the most affected joints were the knee followed by the back, as detected by the two different methods used in our survey, this may be because our body weight is loaded on the knee and the back as reported by the Osteoarthritis Research Society International (OARSI ) who reported that any joint can be affected by osteoarthritis but the disease occurs most commonly in joints that have experienced repetitive stress or injury and the knee is the most common lower-limb joint affected by osteoarthritis ,in addition to hip , hand, foot , ankle and back and neck (16) .

Our study also revealed that, a significant number of students who suffered from arthritis had some difficulties in walking quarter-mile, walking up-stairs, kneeling or stooping, this may also reflect the probability that they are going to suffer from more severe symptoms of arthritis later. Inconsistent with other studies practicing physical exercise did not differ between diagnosed and non-diagnosed groups in this study, a meta-analysis of community-based physical activity interventions indicated that physical activity may enhance the quality of life for those patients by approximately $40 \%(17)$.

We also asked the participants if they had felt any heaviness, numbness or hotness in their joints; students who had been diagnosed by arthritis or had filled the criteria of WHO algorithm had the highest percent of feeling with heaviness, numbness or hotness, but also there were a percent of the non-diagnosed students had felt the same, so we suppose that these students unfortunately may have a chance to be diseased with arthritis in the future.

In our survey we also asked about the medications, and we found that $41.7 \%$ of the students who have arthritis by any of the two methods had taken medication for arthritis, and $90 \%$ of those who took medications, were physician guided, and the rest were self- prescribed medication which may be due to financial constraints or to the availability of these medications as an over the counter drugs or to the availability of pharmacological knowledge as medical students. So, we may need to manage the financial obstacles of out-ofpocket healthcare expenses by encouraging the students' health insurance and screening of this important complain which may lead to many complications, especially as these students are still in their first working life

We have many strengths in our study, the most important one is that we used two methods to measure the prevalence: a symptom-based algorithm according to the Symptom-based questions and the related algorithm defined by the World health organization and self-reported (doctor - healthcare professional diagnosed according to the (NHANES ) ICD 10 , so we could discover the largest possible number of patients in our sample. But also we had some limitations as we used a convenience sampling which makes generalization of our results questionable .so we recommend further studies with random sampling.

\section{Conclusion}

The total prevalence of arthritis among the studied sample was $8.9 \%$ based on both doctor diagnosed and WHO algorithm. Living in urban areas and female gender were the two independent risk factors associated with arthritis. Findings suggest that another study is needed on larger random sample among these age groups, and proper interventions are needed to prevent occurrence of consequences of arthritis later in life, and to prevent the development of the disease among the non- diagnosed group .

\section{Funding}

This research did not receive any specific grant from funding agencies in the public, commercial, or not-for-profit sectors.

\section{References}

1. Brennan-Olsen SL, Cook S, Leech MT, Bowe SJ, Kowal P, Naidoo N, et al. 
Prevalence of arthritis according to age, sex and socioeconomic status in six low and middle income countries: Analysis of data from the World Health Organization study on global AGEing and adult health (SAGE) Wave 1. BMC Musculoskelet Disord. 2017;

2. Vos T, Barber RM, Bell B, BertozziVilla A, Biryukov S, Bolliger I, et al. Global, regional, and national incidence, prevalence, and years lived with disability for 301 acute and chronic diseases and injuries in 188 countries, 1990-2013: A systematic analysis for the Global Burden of Disease Study 2013. Lancet. 2015;

3. Stubbs B, Veronese N, Vancampfort D, Thompson T, Kohler C, Schofield P, et al. Lifetime self-reported arthritis is associated with elevated levels of mental health burden: A multi-national cross sectional study across 46 low-and middleincome countries. Sci Rep. 2017;

4. CDC. Arthritis Types [Internet]. 2019. Available from: https://www.cdc.gov/arthritis/basics/types.ht $\mathrm{ml}$

5. Felson DT, Lawrence RC, Dieppe PA, Hirsch R, Helmick CG, Jordan JM, et al. Osteoarthritis: new insights. Part 1: the disease and its risk factors. Ann Intern Med. 2000 Oct;133(8):635-46.

6. Xu X, Liu L, Xie W, Zhang Y, Zeng $\mathrm{H}$, Zhang $\mathrm{F}$, et al. Increase in the prevalence of arthritis in adulthood among adults exposed to Chinese famine of 1959 to 1961 during childhood: A cross-sectional survey. Medicine (Baltimore). 2017 Mar;96(13):e6496.

7. Briggs AM, Cross MJ, Hoy DG, Sànchez-Riera L, Blyth FM, Woolf AD, et al. Musculoskeletal Health Conditions Represent a Global Threat to Healthy Aging: A Report for the 2015 World Health
Organization World Report on Ageing and Health. Gerontologist. 2016.

8. Murphy LB, Cisternas MG, Greenlund KJ, Giles W, Hannan C, Helmick CG. Defining Arthritis for Public Health Surveillance: Methods and Estimates in Four US Population Health Surveys. Arthritis Care Res. 2017;

9. ICD10 Data. M00-M99 Diseases of the musculoskeletal system and connective tissue , M15-M19 Osteoarthritis [Internet]. 2018. Available from: https://www.icd10data.com/ICD10CM/Code s/M00-M99/M15-M19/M19-/M19.90

10. Kowal P, Chatterji S, Naidoo N, Biritwum R, Fan W, Lopez Ridaura R, et al. Data resource profile: the World Health Organization Study on global AGEing and adult health (SAGE). Int J Epidemiol. 2012 Dec;41(6):1639-49.

11. Mokhtar Abdelhafez A, Mohammad Al-Mashi SS ad. Prevalence of obesity and some related attributes among Umm AlQura university female students in Makkah, Saudi Arabia. Pakistan J Nutr. 2013;

12. WHO. WHO AnthroPlus software [Internet]. 2009. Available from: https://www.who.int/growthref/tools/en/

13. WHO. WHO AnthroPlus for Personal Computers Manual:Software for Assessing Growth of the World's Children and Adolescents. Geneva; 2009.

14. Hootman JM, Helmick CG, Barbour KE, Theis KA, Boring MA. Updated Projected Prevalence of Self-Reported Doctor-Diagnosed Arthritis and ArthritisAttributable Activity Limitation Among US Adults, 2015-2040. Arthritis Rheumatol. 2016;

15. Barbour KE, Helmick CG, Boring M, Brady TJ. Vital signs: Prevalence of Doctor- 
Diagnosed arthritis and arthritis-attributable activity limitation - United States, 20132015. Morb Mortal Wkly Rep. 2017;

16. CDC. Factors that Increase Risk of Getting Arthritis [Internet]. 2019 [cited 2019 Sep 2019]. Available from: https://www.cdc.gov/arthritis/basics/riskfactors.htm

17. Kelley GA, Kelley KS, Hootman JM, Jones DL. Effects of community-deliverable exercise on pain and physical function in adults with arthritis and other rheumatic diseases: A meta-analysis. Arthritis Care Res. 2011; 
Table (1): Symptom-based questions and the related algorithm to ascertain prevalent arthritis, developed as part of the World Health Organization SAGE Wave 1(10)

\begin{tabular}{|c|l|}
\hline Question number & Question text and algorithm \\
\hline 1 & $\begin{array}{l}\text { During the last 12 months, have you experienced } \\
\text { pain, aching, stiffness or swelling in or around the } \\
\text { joints (like arms, hands, legs or feet) which were } \\
\text { not related to an injury and lasted for more than } \\
\text { A month? }\end{array}$ \\
\hline 2 & $\begin{array}{l}\text { During the last 12 months, have your experienced } \\
\text { stiffness in the joint in the morning after getting up } \\
\text { from bed, or after a long rest of the joint without } \\
\text { Movement? }\end{array}$ \\
\hline 3 & $\begin{array}{l}\text { Did this stiffness last for more than 30 min? } \\
\text { Did this stiffness go away after exercise or movement } \\
\text { in the joint? }\end{array}$ \\
\hline Algorithm & $\begin{array}{l}\text { If a participant responded with 'yes' to questions } \\
1 \text { and/or 2, and responded with 'yes' to question } \\
3 \text { and 'no' to question 4, then the participant was } \\
\text { Categorized as having arthritis. }\end{array}$ \\
\hline
\end{tabular}

Table (2): Socio-demographic characteristics of the studied sample

\begin{tabular}{|l|l|}
\hline Variables & $\mathrm{N}(\%)$ \\
\hline Age groups (years) & $104(30.6)$ \\
$18-20$ & $221(65.0)$ \\
$21-23$ & $15(4.4)$ \\
$24-26$ & $112(32.9)$ \\
\hline Sex & $228(67.1)$ \\
Male & $279(82.1)$ \\
Female & $61 \quad(17.9)$ \\
\hline Residence & $310(91.2)$ \\
Urban & $30 \quad(8.8)$ \\
Rural & $15(4.4)$ \\
\hline Body mass index categories & $45(13.2)$ \\
Non-obese & $48(14.1)$ \\
Obese & $77(22.6)$ \\
\hline Grades & $144(42.3)$ \\
$1^{\text {st }}$ & $11(3.2)$ \\
$2^{\text {nd }}$ & \\
$3^{\text {rd }}$ & \\
$4^{\text {th }}$ & $5^{\text {th }}$ \\
$6^{\text {th }}$ & \\
\hline
\end{tabular}


Table (3): Responses to the four questions included in the WHO algorithm for symptom-based arthritis.

\begin{tabular}{|c|c|c|c|c|c|c|c|}
\hline Questions & $\begin{array}{l}\text { Shoulder } \\
\mathrm{N} \\
(\%)\end{array}$ & $\begin{array}{l}\text { Elbow } \\
\mathrm{N} \\
(\%)\end{array}$ & $\begin{array}{l}\text { Wrist } \\
\mathrm{N} \\
(\%)\end{array}$ & $\begin{array}{l}\text { Hip } \\
\mathrm{N} \\
(\%)\end{array}$ & $\begin{array}{l}\text { Ankle } \\
\mathrm{N} \\
(\%)\end{array}$ & $\begin{array}{l}\text { BacklNeck } \\
\mathrm{N} \\
(\%)\end{array}$ & $\begin{array}{l}\text { Knee } \\
\mathrm{N} \\
(\%)\end{array}$ \\
\hline $\begin{array}{l}\text { Any pain during last } 12 \\
\text { months? (yes) }\end{array}$ & $\begin{array}{l}19 \\
(5.6)\end{array}$ & $\begin{array}{l}6 \\
(1.8)\end{array}$ & $\begin{array}{l}13 \\
(3.8)\end{array}$ & $\begin{array}{l}11 \\
(3.2)\end{array}$ & $\begin{array}{l}13 \\
(3.8)\end{array}$ & $\begin{array}{l}36 \\
(10.6)\end{array}$ & $\begin{array}{l}42 \\
(12.4)\end{array}$ \\
\hline $\begin{array}{l}\text { Any stiffness during last } \\
12 \text { months? (yes) }\end{array}$ & $\begin{array}{l}19 \\
(5.6)\end{array}$ & $\begin{array}{l}2 \\
(0.6)\end{array}$ & $6(1.8)$ & $\begin{array}{l}6 \\
(1.8)\end{array}$ & $5(1.5)$ & $\begin{array}{l}33 \\
(9.7)\end{array}$ & $\begin{array}{l}22 \\
(6.5)\end{array}$ \\
\hline $\begin{array}{l}\text { For all joints } \\
\text { Did stiffness last for } \\
>30 \mathrm{~min} \text { ? (yes) }\end{array}$ & \multicolumn{7}{|l|}{$6(6.2)$} \\
\hline $\begin{array}{l}\text { Did stiffness go away } \\
\text { after movement? (No) }\end{array}$ & $7(7.6)$ & & & & & & \\
\hline
\end{tabular}

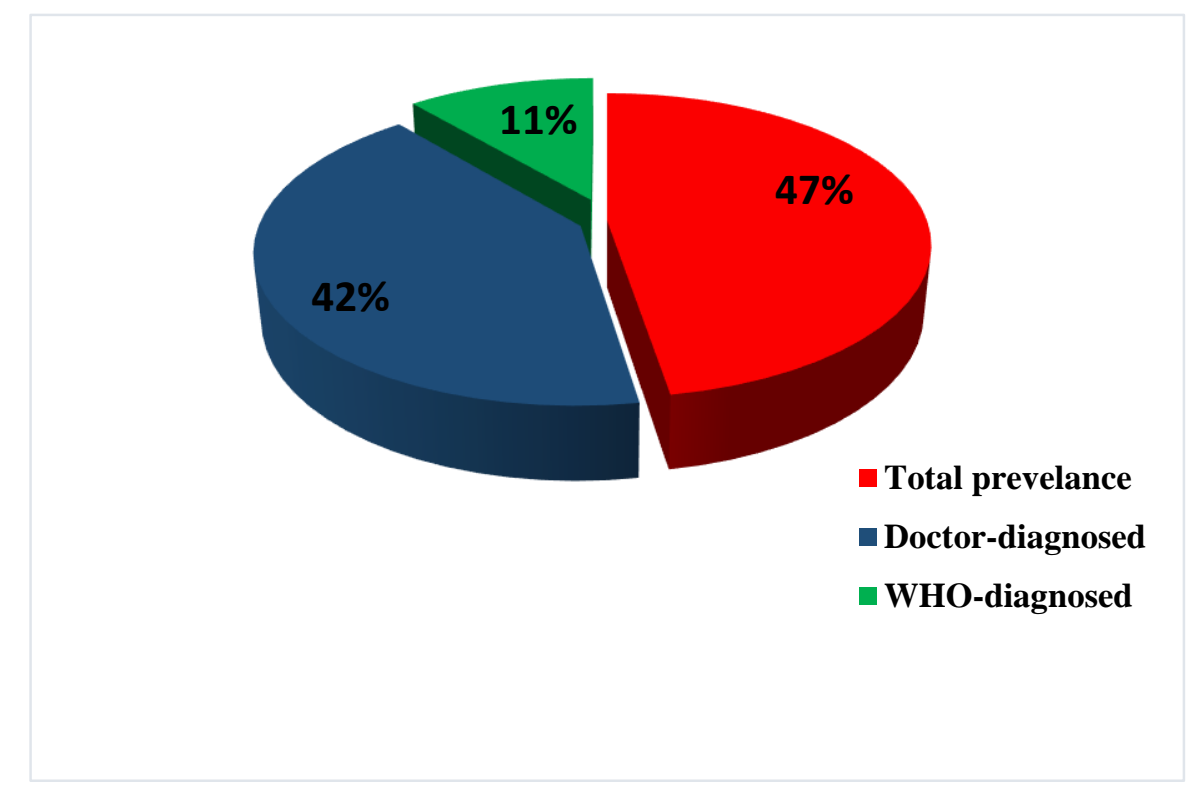

Figure (1) prevalence of arthritis among the studied students 
Table (4): Arthritis prevalence and distribution among students' characteristics $(n=340)$

\begin{tabular}{|c|c|c|c|c|}
\hline Variables & $\begin{array}{l}\text { Total } \\
\text { prevalence } \\
\mathrm{N}(\%)\end{array}$ & $\begin{array}{l}\text { Doctor } \\
\text { diagnosed } \\
\mathrm{N}(\%)\end{array}$ & $\begin{array}{l}\text { WHO } \\
\text { algorithm } \\
\mathrm{N}(\%)\end{array}$ & $\begin{array}{l}\text { Non- } \\
\text { diagnosed } \\
\mathrm{N}(\%)\end{array}$ \\
\hline Overall arthritis prevalence $*$ & $30(8.9)$ & $24(7.1)$ & $7(2.1)$ & $310(91.1)$ \\
\hline \multicolumn{5}{|c|}{ Socio-demographic characteristics } \\
\hline $\begin{array}{l}\text { Age groups (years) } \\
18- \\
21-23 \\
24-26\end{array}$ & $\begin{array}{l}8(26.7) \\
22(73.3) \\
0(0)\end{array}$ & $\begin{array}{l}8(33.3) \\
16(66.7) \\
0(0)\end{array}$ & $\begin{array}{l}0(0) \\
7(100) \\
0(0)\end{array}$ & $\begin{array}{l}96(31.3) \\
199(64.2) \\
15(4.6)\end{array}$ \\
\hline $\begin{array}{l}\text { Sex } \\
\text { Men } \\
\text { Women } \\
\text { P value }(0.006) \\
\end{array}$ & $\begin{array}{l}3(10) \\
27(90)\end{array}$ & $\begin{array}{l}3(12.5) \\
21(87.5)\end{array}$ & $\begin{array}{l}0(0) \\
7(100)\end{array}$ & $\begin{array}{l}107(34.5) \\
203(65.5)\end{array}$ \\
\hline $\begin{array}{l}\text { Grades } \\
1^{\text {st }} \\
2^{\text {nd }} \\
3^{\text {rd }} \\
4^{\text {th }} \\
5^{\text {th }} \\
6^{\text {th }} \\
\text { P value }(0.562) \\
\end{array}$ & $\begin{array}{l}0(0) \\
6(20) \\
4(13.3) \\
6(20) \\
14(46.7) \\
0(0)\end{array}$ & $\begin{array}{l}0(0) \\
6(25) \\
4(16.7) \\
3(12.5) \\
11(45.8) \\
0(0)\end{array}$ & $\begin{array}{l}0(0) \\
0(0) \\
0(0) \\
3(42.9) \\
4(57.1) \\
0(0)\end{array}$ & $\begin{array}{l}15(4.9) \\
39(12.7) \\
44(14.3) \\
71(22.8) \\
130(42) \\
11(3.3)\end{array}$ \\
\hline $\begin{array}{l}\text { Residence } \\
\text { Urban } \\
\text { Rural } \\
\text { P value }=0.005\end{array}$ & $\begin{array}{l}19(63.3) \\
11(36.7)\end{array}$ & $\begin{array}{l}15(62.5) \\
9(37.5)\end{array}$ & $\begin{array}{l}5(71.4) \\
2(28.6)\end{array}$ & $\begin{array}{l}260(84) \\
50(16)\end{array}$ \\
\hline $\begin{array}{l}\text { Educational level of father } \\
\text { Illiterate } \\
\text { Primary school } \\
\text { Secondary school } \\
\text { University } \\
\text { P value }(0.977)\end{array}$ & $\begin{array}{l}0(0) \\
1(3.3) \\
5(16.7) \\
24(80)\end{array}$ & $\begin{array}{l}0(0) \\
0(0) \\
4(16.7) \\
20(83.3)\end{array}$ & $\begin{array}{l}0(0) \\
1(14.3) \\
1(14.3) \\
5(71.4)\end{array}$ & $\begin{array}{l}2(0.7) \\
10(3.3) \\
49(16) \\
247(80.1)\end{array}$ \\
\hline $\begin{array}{l}\text { Educational level of mother } \\
\text { Illiterate } \\
\text { Primary school } \\
\text { Secondary school } \\
\text { University } \\
\text { P value (0.949) }\end{array}$ & $\begin{array}{l}2(6.7) \\
1(3.3) \\
5(16.7) \\
22(73.3) \\
\end{array}$ & $\begin{array}{l}2(8.3) \\
0(0) \\
4(16.7) \\
18(75) \\
\end{array}$ & $\begin{array}{l}0(0) \\
1(14.3) \\
1(14.3) \\
5(71.4)\end{array}$ & $\begin{array}{l}14(4.6) \\
8(2.6) \\
55(17.6) \\
233(75.2) \\
\end{array}$ \\
\hline $\begin{array}{l}\text { Body mass index categories, } \\
\text { Underweightlnormal weight } \\
\text { Over weight } \\
\text { Obese } \\
\text { P value }(0.64)\end{array}$ & $\begin{array}{l}17(56.7) \\
9(30) \\
4(13.3)\end{array}$ & $\begin{array}{l}14(58.3) \\
7(29.2) \\
3(12.5)\end{array}$ & $\begin{array}{l}4(57.1) \\
2(28.6) \\
1(14.3)\end{array}$ & $\begin{array}{l}192(61.9) \\
92(29.6) \\
26(8.5)\end{array}$ \\
\hline $\begin{array}{l}\text { Self-rated health } \\
\text { Excellent } \\
\text { Very good } \\
\text { Good } \\
\text { Fair } \\
\text { Poor } \\
\text { P value }(<0.001)\end{array}$ & $\begin{array}{l}1(3.3) \\
14(46.7) \\
7(23.3) \\
5(16.7) \\
3(10)\end{array}$ & $\begin{array}{l}1(4.2) \\
11(45.5) \\
5(20.8) \\
4(16.7) \\
3(12.5)\end{array}$ & $\begin{array}{l}0(0) \\
4(57.1) \\
2(28.6) \\
1(14.3) \\
0(0)\end{array}$ & $\begin{array}{l}43(14) \\
159(51.1) \\
94(30.3) \\
10(3.3) \\
4(1.3)\end{array}$ \\
\hline
\end{tabular}

*one individual diagnosed by two methods

$\mathrm{p}$ value was estimated using chi-square test between total prevalence and non- diagnosed groups 
Table (5): Daily life activities among the studied students $(n=340)$

\begin{tabular}{|c|c|c|c|c|}
\hline Variables* & $\begin{array}{l}\text { Total } \\
\text { prevalence } \\
\mathrm{N}=30 \\
\mathrm{~N}(\%)\end{array}$ & $\begin{array}{l}\text { Doctor } \\
\text { diagnosed } \\
\mathrm{N}=24 \\
\mathrm{~N}(\%)\end{array}$ & $\begin{array}{l}\text { WHO } \\
\text { algorithm } \\
\mathrm{N}=7 \\
\mathrm{~N}(\%)\end{array}$ & $\begin{array}{l}\text { Non- } \\
\text { diagnosed } \\
\mathrm{N}=310 \\
\mathrm{~N}(\%)\end{array}$ \\
\hline $\begin{array}{l}\text { Any difficulty walking quarter mile (2-3) } \\
\text { blocks } \\
\text { P value }(0.100)\end{array}$ & $7(23.3)$ & $7(29.2)$ & $0(0)$ & $39(12.7)$ \\
\hline $\begin{array}{l}\text { Any difficulty walking up to } 10 \text { steps } \\
\text { without rest } \\
\text { P value }(0.002)\end{array}$ & $11(36.7)$ & $10(41.7)$ & $1(14.3)$ & $46(14.7)$ \\
\hline $\begin{array}{l}\text { Any difficulty stooping, crouching, or } \\
\text { kneeling } \\
\mathrm{P} \text { value }(<0.001)\end{array}$ & $13(43.3)$ & $11((45.8)$ & $2(28.6)$ & $30(9.7)$ \\
\hline $\begin{array}{l}\text { Any difficulty using fingers to grasp or } \\
\text { handle small objects } \\
\mathrm{P} \text { value(0.612) }\end{array}$ & $3(10.0)$ & $3(12.5)$ & $0(0)$ & $23(7.5)$ \\
\hline $\begin{array}{l}\text { How do you go to faculty? } \\
\text { Transportation } \\
\text { Walking } \\
\text { P value }(0.220)\end{array}$ & $\begin{array}{l}26(86.7) \\
4(13.3)\end{array}$ & $\begin{array}{l}20(83.3) \\
4(16.7)\end{array}$ & $\begin{array}{l}7(100) \\
0(0)\end{array}$ & $\begin{array}{l}288(92.9) \\
22(7.1)\end{array}$ \\
\hline $\begin{array}{l}\text { Practice sports } \\
\text { Yes } \\
\text { No } \\
\text { P value }(0.451) \\
\end{array}$ & $\begin{array}{l}20(66.7) \\
10(33.3)\end{array}$ & $\begin{array}{l}18(75.0) \\
6(25.0)\end{array}$ & $\begin{array}{l}3(42.9) \\
4(57.1\end{array}$ & $\begin{array}{l}179(57.7) \\
131(42.3)\end{array}$ \\
\hline
\end{tabular}

*p value was estimated using chi-square test between total prevalence and non- diagnosed groups

Table (6) Logistic regression analysis for the variables associated with arthritis

\begin{tabular}{|l|l|l|l|}
\hline Variables & \multicolumn{1}{|c|}{ P value } & Odds ratio & 95\% C.I \\
\hline $\begin{array}{l}\text { Gender } \\
\text { Male (Reference.) }\end{array}$ & --- & --- & \\
Female & 0.015 & 4.623 & $1.352-15.809$ \\
\hline Age & 0.456 & 1.106 & $0.848-1.442$ \\
\hline $\begin{array}{l}\text { Residence } \\
\text { Urban } \\
\text { Rural( reference) }\end{array}$ & 0.015 & 2.822 & $1.226-6.497$ \\
\hline $\begin{array}{l}\text { BMI categories } \\
\text { Non- obese (reference) } \\
\text { Obese }\end{array}$ & --- & --- & $0.206-2.161$ \\
\hline
\end{tabular}




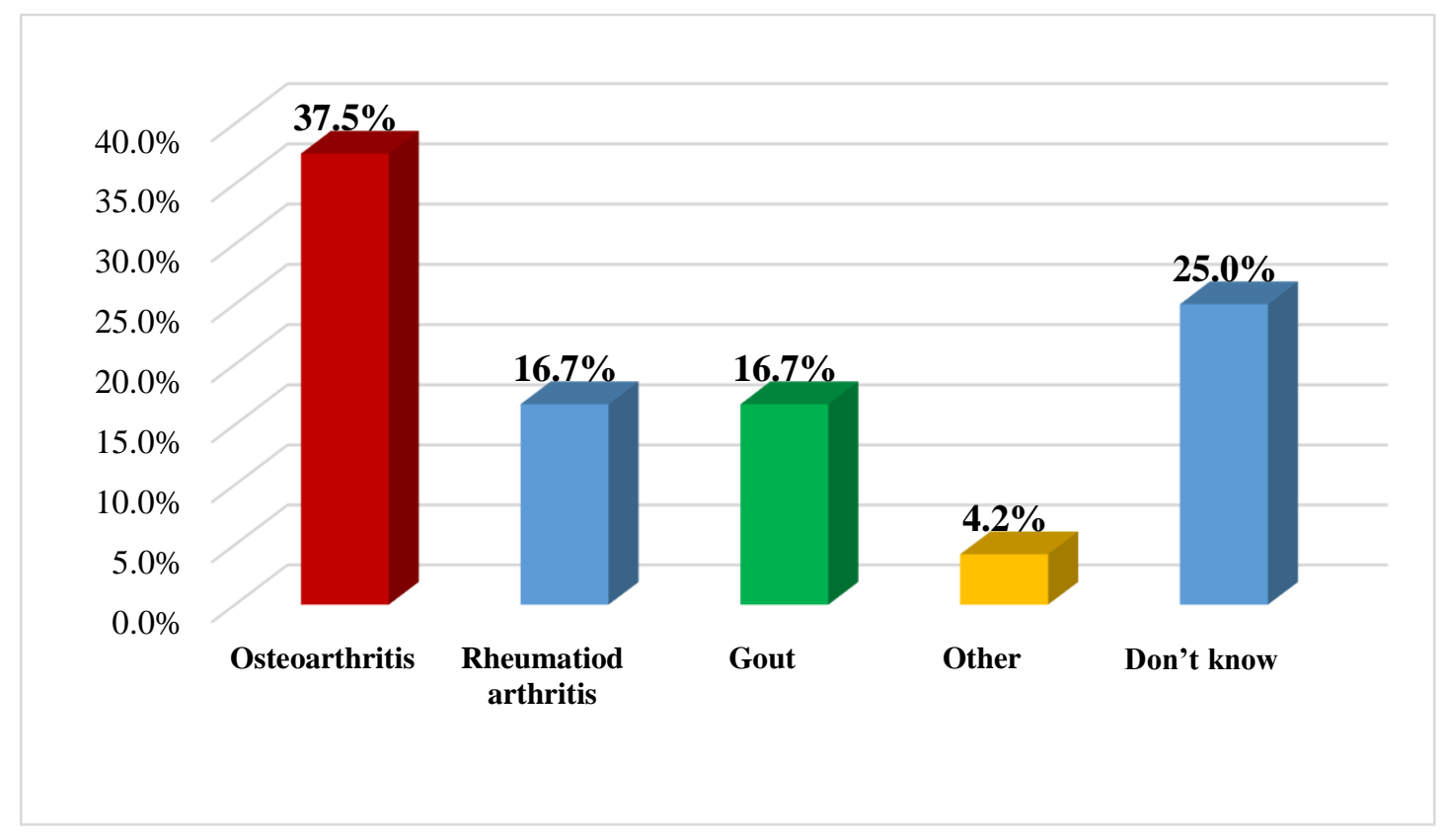

Figure (2) Types of arthritis among students diagnosed based on doctor diagnosed method.

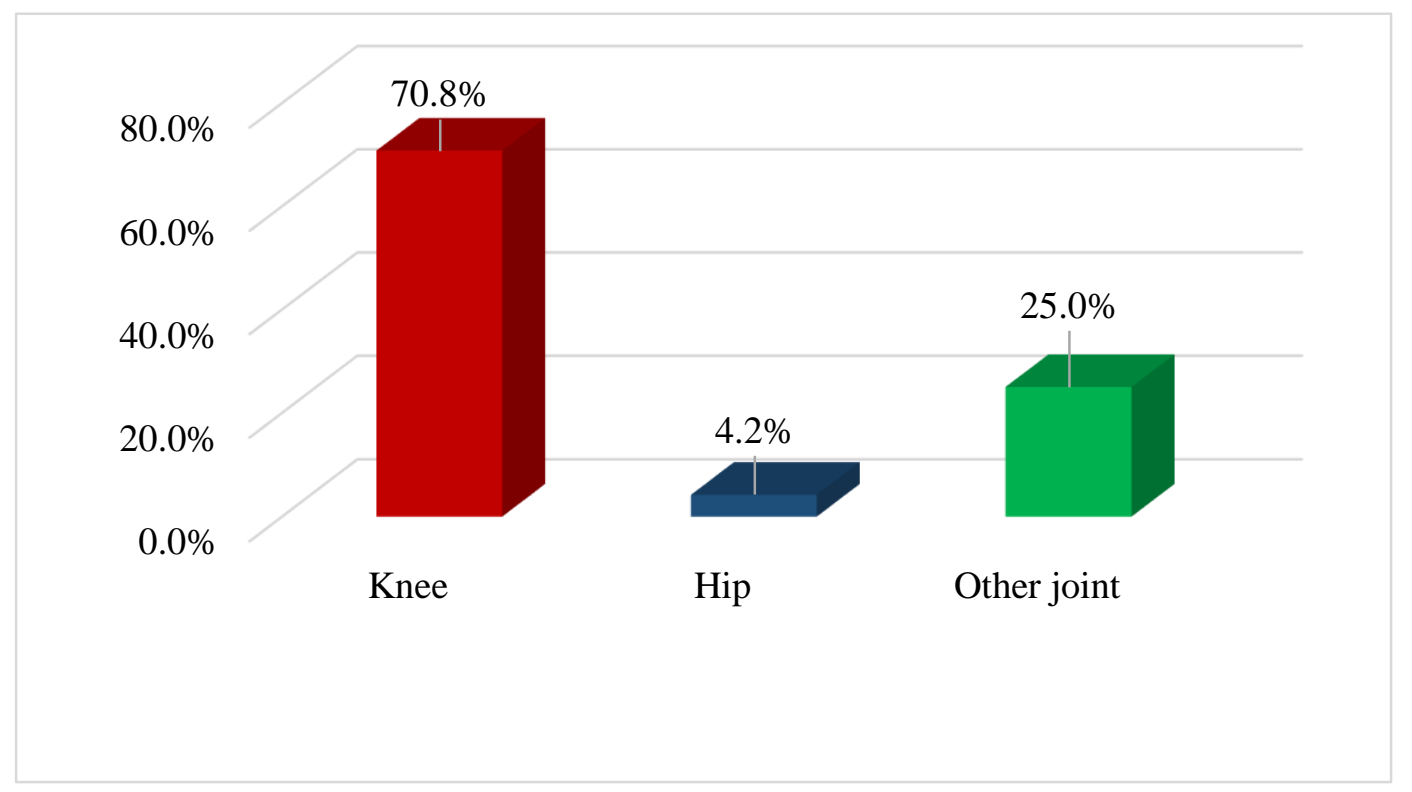

Figure (3) Distribution of the most affected joints based on doctor diagnosed method 